\title{
EFFECT OF PLANT CONDITION ON OVIPOSITION BY RAGWORT FLEA BEETLE
}

\author{
B. PAGE ${ }^{1}$, K. BETTERIDGE 2 , P.G. McGREGOR ${ }^{3}$, J. RAPSON ${ }^{4}$ and \\ D.A. COSTALL ${ }^{1}$
}

\author{
${ }^{1}$ New Zealand Institute for Crop \& Food Research Limited, Private Bag 11 600, \\ Palmerston North \\ ${ }^{2}$ Agresearch Grasslands, Private Bag 11 008, Palmerston North \\ ${ }^{3}$ Landcare Research, Private Bag 11 052, Palmerston North \\ ${ }^{4}$ Institute of Natural Resources, Private Bag 11 222, Massey University, \\ Palmerston North \\ Corresponding author: pageb@crop.cri.nz.
}

\begin{abstract}
The impact of grazing animals on oviposition behaviour of ragwort flea beetle (RFB) (Longitarsus jacobaeae) was investigated in two field experiments. In the first trial manually 'damaged' ragwort plants were exposed for 5 days to RFB. In the second trial, ragwort plants grown in sheep and cattle-grazed pasture were collected both in April and May 1997 for the counting of eggs on plants and in the surrounding soil. Removal of the majority of ragwort leaves reduced egg numbers/plant whereas damage to leaves did not. Similarly, ragwort from sheep-grazed pastures, which was smaller than ragwort from cattle-grazed pastures, had fewer eggs/plant but a similar number/g fresh weight of ragwort. High local humidity under rosette ragwort plants is suggested as the critical factor determining oviposition behaviour of RFB.

Keywords: Longitarsus jacobaceae, ragwort flea beetle, ragwort, oviposition.
\end{abstract}

\section{INTRODUCTION}

The process of competition is one where the presence of one species lowers the availability of the resources for the other. Competing species may also indirectly affect each other's reproductive capacity (Wood \& Lee 1970). Competition is most intense when there is a finite food source, such as with ragwort in grazed pastures. Ragwort flea beetle (RFB), a specialised insect which consumes and oviposits solely on ragwort plants, competes with sheep which also eat ragwort (Betteridge et al. 1994).

Little is known about the effects of stock grazing on the egg laying behaviour of RFB. Sutherland et al. (2000) reported that approximately $90 \%$ of a flock of Romney sheep readily consumed ragwort, often removing all leaves within 24 hours, even when pasture was plentiful. Sheep favour the rosette ragwort plant form, which is also preferred by adult RFB (McEvoy et al. 1991; Windig 1993). Grazing by sheep reduces the size and number of ragwort plants (Betteridge et al. 1994) whereas cattle, which avoid ragwort, allow ragwort cover to increase (Amor et al. 1983). Plant damage by cattle is more likely to be due to trampling than grazing.

We studied RFB oviposition behaviour through the distribution of RFB eggs under both simulated and actual livestock grazing. These treatments may destroy eggs directly and alter the proportion of plants that are suited to oviposition.

\section{METHODS}

Plant damage and canopy removal (Trial 1)

This trial measured the effects of artificial damage to ragwort on oviposition density by RFB. The trial was conducted in a grass lawn at the Crop \& Food Research Centre, Levin. 
In winter 1995, ragwort seeds were sown in 5 litre polythene pots, in a standard potting medium (2:1:1 ratio by volume of bark, pumice and peatmoss). Plants were established in an insect-proof glasshouse and used in April 1996 when they were at the mature rosette stage. Five replicate groups of nine plants, based on plant size and shape, were formed. Three individual plants within each replicate were randomly assigned to one of three treatments. Treatment 1 consisted of plants that had been damaged by stabbing leaves with a wire brush, leaving holes in over $50 \%$ of the leaf surface to simulate damage by stock movement. This did not reduce the overall apparent leaf canopy size and kept midribs intact. In Treatment 2 , to simulate sheep grazing, the rosette canopies were reduced to $25 \%$ of the original size by cutting leaves where the petiole joined the stem. The control (Treatment 3) consisted of plants with undamaged leaves. The pots containing the ragwort plants were buried in the lawn such that the soil surface in the pot was level within the lawn surface. Each replicate of nine plants was arranged in a random sequence in a circular pattern, at a $1 \mathrm{~m}$ radius from a central point from which beetles were released. The replicated plots were separated by a distance of $75 \mathrm{~m}$ to avoid beetle dispersal between plots.

Twenty-five female and five male RFB were randomly allocated to each replicate on 3 April 1996. Beetles were released early in the morning, by placing an opened jar in the centre of the circle of ragwort plants and allowing beetles to disperse naturally. Plants were removed after 5 days and eggs were recovered and counted (see below). Differences in egg number between treatments were assessed by analysis of variance using the Minitab (12.0 version) statistical procedure. Natural logarithm transformations of egg numbers/unit fresh weight of plant were used to homogenize variance.

\section{Stock grazing effects (Trial 2)}

In the second experiment sheep and cattle grazing was used to alter ragwort's morphology to study how plant form influenced ovipositioning rate of RFB. The study was carried out at the AgResearch Research Station, Ballantrae. Three areas, each having an established population of RFB, were used as replicates and were separated by at least $300 \mathrm{~m}$.

From late February 1997 until early May 1997, ragwort plants were studied within two fenced $10 \mathrm{~m} \times 20 \mathrm{~m}$ blocks within each replicate, with each block assigned to one of the grazing treatments. Sheep were stocked at an equivalent annual rate of 12 sheep units/ha, once every 2 weeks, and cattle were rotationally grazed in these blocks at a similar stocking rate, every 20 to 25 days. In December 1996, 40 rosette plants (at least one year old) from a beetle-free area were collected using a $100 \mathrm{~mm}$ diameter soil corer and transplanted, with roots and soil intact, into each of the two blocks within each replicate. Plants were set out in several lines with $0.5 \mathrm{~m}$ between plants. After plants had been transplanted, blocks were sprayed with Orthene to remove resident RFB from plots and sprayed twice with Dipel $0.5 \mathrm{~g} /$ /itre Bacillus thuringienis var. Kurstaki over early summer to minimise cinnabar moth damage on establishing plants. There was a 16 week establishment period with intermittent sheep and cattle grazing and full exposure to reinvading RFB. This ensured that plants developed a different morphological form before measurements commenced. RFB oviposition rates were determined on 8 April and 23 May 1997.

Five random ragwort plants and their root systems were removed from each grazing block within each replicate. A $130 \mathrm{~mm}$ diameter soil corer was used to collect the plant and its associated soil. Plant height and diameter of the ground surface covered by leaves (mean of two measurements taken at right angles across the rosette) were recorded. Analysis of variance was used to compare numbers of eggs laid in the two stock grazing treatments.

\section{Egg collection}

Plants recovered from the field were cut at ground level. Plant tops were wet sieved sequentially through a series of sieves of mesh size $5.91 \mathrm{~mm}, 500 \mu \mathrm{m}$ and finally a fine cloth sieve of $250 \mu \mathrm{m}$ diameter; the latter sieve being too small for eggs to pass through. The soil and roots, dispersed in warm water, were also washed over these sieves. Eggs 
from the leaves were transferred to a vial for counting. Eggs from the soil were extracted from the residue using a salt flotation technique (Rohitha 1992) in which a saturated magnesium sulphate $\left(\mathrm{Mg}_{2} \mathrm{SO}_{4}\right)$ salt solution (specific gravity 1.22 at $20^{\circ} \mathrm{C}$ ) was used to float the eggs from the soil residues. The supernatant was decanted through the finest sieve and eggs were retrieved for counting. All eggs were counted using a binocular microscope (40X).

\section{RESULTS AND DISCUSSION}

In Trial 1, clipped plants were lighter than unclipped and control plants and had significantly fewer eggs/g fresh weight (Table 1).

TABLE 1: Mean ( \pm SE) ragwort fresh weight (leaves + roots) and egg count on ragwort plants 5 days after RFB were released at a distance of $1 \mathrm{~m}$.

\begin{tabular}{lcccc}
\hline Treatment & \multicolumn{2}{c}{ Fresh weight $(\mathrm{g})$} & \multicolumn{2}{c}{ No. eggs/g fresh weight } \\
\hline Clipped & 25 & $(1.6)$ & 5 & $(2.1)$ \\
Damaged & 109 & $(7.9)$ & 49 & $(10.3)$ \\
Control & 97 & $(8.0)$ & 59 & $(9.0)$ \\
\hline
\end{tabular}

In the field trial (Trail 2), as expected, sheep-grazed ragwort was shorter and had a smaller ground cover than cattle-grazed plants. The plants were smaller in May than in April, possibly because of grazing and trampling damage (Table 2).

TABLE 2: Mean $( \pm$ SE) RFB egg count and ragwort plant dimensions in sheep and cattle-grazed pastures at two sampling dates.

\begin{tabular}{llcccccc}
\hline Sampling date & $\begin{array}{c}\text { Grazing } \\
\text { management }\end{array}$ & \multicolumn{2}{c}{$\begin{array}{c}\text { Plant height } \\
(\mathrm{cm})\end{array}$} & $\begin{array}{c}\text { Rosette ground } \\
\text { cover }\left(\mathrm{cm}^{2}\right)\end{array}$ & \multicolumn{2}{c}{$\begin{array}{c}\text { No. } \\
\text { eggs/plant }\end{array}$} \\
\hline 8 April 1997 & Sheep & 8.4 & $(1.0)$ & 411 & $(107.1)$ & 31.0 & $(7.5)$ \\
& Cattle & 15.2 & $(1.2)$ & 697 & $(98.1)$ & 77.0 & $(13.4)$ \\
29 May 1997 & Sheep & 4.4 & $(0.4)$ & 120 & $(44.7)$ & 0.8 & $(0.2)$ \\
& Cattle & 6.8 & $(0.9)$ & 352 & $(81.3)$ & 1.8 & $(0.6)$ \\
\hline
\end{tabular}

While sheep-grazed ragwort plants had fewer eggs oviposited on them than the cattle grazed plants, there was no difference between the numbers of eggs laid $/ \mathrm{cm}^{2}$ of ground cover between the two grazing managements $(\mathrm{P}>0.05)$. It is difficult to explain why there were so few eggs recovered at the second sampling, as egg laying is known to continue until September (B. Page, unpubl. data).

Zhang and McEvoy $(1995,1996)$ showed that olfactory cues were the primary attractant of RFB. They found that the RFB response did not change significantly when large numbers of ragwort plants, or plants with different numbers of leaves, were presented. In the present study, results showed that although small plants did attract RFB, they had a reduced number of eggs laid on, or near each plant. We suggest that this was because the removal of the leaf canopy altered the micro-environment at the plant base (and surrounding soil) where flea beetles lay most of their eggs. We measured relative humidity under rosette and flowering ragwort plants using Tiny Tag data loggers. Under a mature rosette, relative humidity was diurnally stable at $90-100 \%$, compared to a diurnally unstable relative humidity of $40-100 \%$ at the base of a flowering plant (B. Page, unpubl. data). One of the most critical times in the beetle's life history is egg survival and the immediate survival of the larvae after hatching. Keeping RFB eggs moist is vital to their 
survival as eggs desiccate and become non-viable below $85 \%$ relative humidity (Frick \& Johnson 1972; Delpachitra 1991). However, once larvae have entered the root crown or petiole, humidity is unlikely to be of any further importance to the development of the RFB larvae.

An understanding of the effects of stock grazing on numbers of eggs laid may be useful to land managers. Grazing ragwort-infested pasture with sheep results in ragwort control through reduction in plant size and density (Betteridge et al. 1994), however this also reduces the number of 'ideal' oviposition sites for RFB, a form of indirect competition. Ragwort often regenerates quickly after removal of sheep from the pasture, and grazing at a low stocking rate often results in long-lived, multi-crowned ragwort plants. Thus, it is unclear what long-term impact sheep grazing would have on the establishment of an effective RFB population. Maintaining large rosettes and a dense pasture cover during the egg-laying period would provide ideal conditions to encourage oviposition by adult RFB and optimise larval hatching.

\section{REFERENCES}

Amor, R.L.; Lane, D.W.; Jackson K.W. 1983: Observations on the influence of grazing by sheep and cattle on the density of ragwort. Aust. Weeds 2: 94-95.

Betteridge, K.; Costall, D.A.; Hutching, S.M.; Devantier, B.P.; Liu, Y. 1994: Ragwort (Senecio jacobaeae) control by sheep in a hill country bull beef system. Proc. 47th N.Z. Plant Prot. Conf.: 53-57.

Delpachitra, N.D. 1991: Some aspects of the biology of the RFB Longitarsus jacobaeae relating to its role as a biological control agent in New Zealand. Unpublished Masters thesis, Lincoln University, Canterbury, New Zealand.

Frick, K.E.; Johnson, G.R. 1972: Longitarsus jacobaeae (Coleoptera: Chrysomeliadae), a flea beetle for the biological control of tansy ragwort. 3: Comparison of the biologies of the egg stage of Swiss and Italian biotypes. Annals Entomol. Soc. America 5: 407-410.

McEvoy, P.B.; Cox, C.S.; Coombs, E.M. 1991: Successful biological control of ragwort, Senecio jacobaeae by introduced insects in Oregon. Ecol. Applic. 1: 430-442.

Rohitha, B. 1992: A simple separation system based on flotation for small samples of insects contaminated with soil. N.Z. Entomol 15: 81-83.

Sutherland, R.J.; Betteridge, K.; Fordham, R.A.; Stafford, K.J.; Costall, D.A. 2000: Effects of rearing environment on Tansy Ragwort grazing by lambs. J.Range Mgt 54: 432-436.

Windig, J.J. 1993: Intensity of Longitarsus jacobaeae herbivory and mortality on Senecio jacobaeae. J. Appl. Ecol. 30:179-186.

Wood, T.G.; Lee, K.E. 1970: Abundance of mounds and competition among colonies of some Australian termite species. Pabobiologia 11:341-346.

Zhang, Z.; McEvoy P.B. 1995: Responses of the RFB Longitarsus jacobaeae (Coleoptera: Chrysomeliadae) to signals from host plants. Bull. Ecol. Res. 85: 437-444.

Zhang, Z.; McEvoy P.B. 1996: Factors affecting the response of Longitarsus jacobaeae (Coleoptera: Chrysomeliadae) to upwind plant odours. Bull Ecol. Res. 86: 307313. 